\title{
EFFECT OF CALCIUM CYANAMIDE ON PATHOGENIC ESCHERICHIA COLI DURING MESOPHILIC COMPOSTING AND IMPACT ON COMPOSTING PROCESS
}

\author{
H. SIMUJIDE ${ }^{1}$ \\ C. AORIGELE ${ }^{1, *}$ \\ C.J. WANG ${ }^{2}$ \\ B. MANDA ${ }^{1}$ \\ L.N. $M^{3}$
}

\author{
${ }^{1}$ Animal Production Laboratory, College of Animal Science, \\ Inner Mongolia Agricultural University, \\ Hohhot 010018, China \\ ${ }^{2}$ Basic Veterinary Medicine Laboratory, College of Veterinary Medicine, \\ Inner Mongolia Agricultural University, \\ Hohhot 010018, China \\ ${ }^{3}$ College of Life Sciences, \\ Inner Mongolia Agricultural University, \\ Hohhot 010018, China
}

*to whom all correspondence should be addressed:

Accepted: 06/04/12 e-mail: aori60@yahoo.com.cn

\begin{abstract}
The objective of the study was to determine the effect of $\mathrm{CaCN}_{2}$ on pathogenic $E$. coli as an antimicrobial agent and its impact on composting progress as an amendment in dairy cow manure based mixtures composted at laboratory scale. The changes in physical parameters, chemical parameters and biological parameters during 63 days composting were evaluated. The results of the analysis revealed that additions of $2 \%$ and $3 \% \mathrm{CaCN}_{2}$ into the compostable substrate significantly improved the quality of the composting products. And the test for inactivation of $E$. coli showed that additions of $2 \%$ and $3 \% \mathrm{CaCN}_{2}$ significantly shortened the time to inactivate $E$. coli during composting, indicating that the composting could quickly reach the sanitary standard with the addition of $\mathrm{CaCN}_{2}$.
\end{abstract}

KEYWORDS: zoonotic pathogen, antimicrobial agent, cattle, manure, waste management technologies.

\section{INTRODUCTION}

Composting is not only the most efficient way to produce an agronomically advantageous soil organic amendment, but is also one of the most environmentally friendly treatments to inactivate pathogenic organisms or reduce them to acceptable levels (Boulter et al., 2000, Wichuk and McCartney 2007). And much work has been done to investigate the pathogen destructive and disease suppressive effect of composting worldwide. Pathogenic $E$. coli has a great capacity to survive for long periods in manure. In a laboratory-scale bioreactor, E. coli $0157: \mathrm{H} 7$ still survived in manure composting at $21^{\circ} \mathrm{C}$ after $36 \mathrm{~d}$, while not detected $14 \mathrm{~d}$ post-composting in a temperature of $50{ }^{\circ} \mathrm{C}$ (Jiang et al., 2003). Our previous test showed that when the fresh bovine fecal samples inoculated with $E$. coli $\mathrm{O} 2$ and $\mathrm{O} 8$ were heated at $50{ }^{\circ} \mathrm{C}$ and $60{ }^{\circ} \mathrm{C}$, E. coli $\mathrm{O} 2$ was not detectable from $10 \mathrm{~d}$ in $50{ }^{\circ} \mathrm{C}$ and from $5 \mathrm{~d}$ in $60^{\circ} \mathrm{C}$ during composting. However, E. coli $\mathrm{O} 8$ was not detected from $3 \mathrm{~d}$ and $1 \mathrm{~d}$ in $50{ }^{\circ} \mathrm{C}$ and $60{ }^{\circ} \mathrm{C}$, respectively (data not shown). The result demonstrated that even under thermal conditions, some strains of pathogenic $E$. coli could exist for a long time in composting. Such great persistence may increase the possibility of the outbreaks of this organism and further increase the environmental load.

Calcium cyanamide $\left(\mathrm{CaCN}_{2}\right)$, which has been mainly used as a fertilizer for a long time, has recently been recognized to have the fungicidal effect on the pathogens of the soilborne diseases. The $\mathrm{CaCN}_{2}$ effectively suppressed Fusarium solani f.sp. cucurbitae in greenhouse cucumber (Bourbos et al., 1997), and was also fungicidal to Fusarium oxysporum f. sp. Cucumberinum (Shi et al., 2009). 
However, very little is known about its effect on zoonotic microorganisms. The present research, for the first time, tried to elucidate the impact of $\mathrm{CaCN}_{2}$ on pathogenic $E$. coli with different serotypes during mesophilic composting of cow manure, which was aimed to inhibit the pathogens that had not been inactivated by heat.

\section{MATERIALS AND METHODS}

\section{Analytical methods}

\section{Physico-chemical analysis}

The temperatures of all treatments and the environment (surrounding temperature of composting reactor) were measured daily at 9:00 $\mathrm{AM}$ and 16:00 PM. The moisture contents of the samples were determined after oven drying at $105^{\circ} \mathrm{C}$ to a constant weight (Bao 2000). The $\mathrm{pH}$ was determined by a Mettler-Toledo EL20 pH-meter (Mettler-Toledo international trading (Shanghai) Co., Ltd.). Total nitrogen (T-N) analysis was performed using kjeldahl method (Bao 2000). Total carbon (T-C) was measured by $\mathrm{K}_{2} \mathrm{Cr}_{2} \mathrm{O}_{7}$ volumetric method (Bao 2000).

\section{Seed germination test}

Seed germination test was carried out on filter paper lined in petri dishes (Huang,. 2004). Aqueous extract from the composting samples was prepared by mechanically shaking for $2 \mathrm{~h}$ and centrifugation at $4000 \mathrm{rpm}$ for $20 \mathrm{~min}$ at a solid: $\mathrm{ddH}_{2} \mathrm{O}$ (double distilled water) ratio of 1:8 (w/v, dry weight basis). $5.0 \mathrm{~mL}$ each extract was pipetted into a petri dish, and 25 seeds of rape (Brassica napus L.) were evenly placed on the filter paper and incubated at $25{ }^{\circ} \mathrm{C}$ for $96 \mathrm{~h}$ in darkness. Meanwhile, $\mathrm{ddH}_{2} \mathrm{O}$ was used as an extract of the controls. Each sample was analyzed in quintuplicate. A germination index $(\mathrm{Gl})$ was determined by counting the number of germinated seeds and measuring the length of roots. A formula for calculating $\mathrm{GI}$ was as follows:

$$
G I(\%)=\frac{\text { seed germination } \times \text { root length of treatment }}{\text { seed germination } \times \text { root length of control }} \times 100 \%
$$

\section{Microbiological analysis}

To determine the fecal indicator bacteria E. coli, serial dilutions $(1: 10)$ of the composting samples with sterile physiological saline were performed, and then homogenized for $10 \mathrm{~min}$ in a rotatory stirrer. E. coli was investigated from eosin-methylene blue agar (EMB) plates and confirmed by Indole Test (Cohen et al., 2005).

\section{Composting process}

The sawdust was collected from a wood treatment plant, and fresh manure of healthy dairy cow was collected from a cow farm. The fresh manure was confirmed to carry none of the virulence factors used in the study by PCR technique. At the beginning of the composting, all treatments were adjusted their moisture content at a level between $65 \%$ and $70 \%$.

A schematic diagram of the composting reactor used in this study is shown in Figure 1. A fine screen mesh was installed about $5 \mathrm{~cm}$ above the reactor bottom to segregate the compost pile from the aeration channel. Ten $\mathrm{kg}$ of the mixtures were composted in the composting reactors for $63 \mathrm{~d}$ by air supplying through the regular turning. And $10 \mathrm{~g}$ of sample in duplicate was collected from each treatment by using quartering process at days $0,1,3,4,7,14,21,28,35,42,49,56$, and 63 for the analysis of different parameters.

All treatments were classified into test treatment and control treatment. The test treatment was further divided into treatment I and treatment II. $\mathrm{CaCN}_{2}$ in the form of solid was thoroughly mixed with composting mixtures of test treatments at the additive contents of $2 \%$ and $3 \%$ by weight respectively, while was not added to control treatment. Then, each treatment was separately injected with an inoculum of $200 \mathrm{~mL} 1 \times 10^{8} \mathrm{cfu} \cdot \mathrm{mL}^{-1}$ of $E$. coli O2 (group I), E. coli O78 (group II), and $E$. coli 086 (group III). The E. coli strains originated from the manure of healthy dairy cows and were, in our previous study, confirmed that all of them carried the virulence factors of pathogenic $E$. coli, that the strain with serotype $\mathrm{O} 2$ carried $b f p A$, the strain with serotype $\mathrm{O} 78$ carried st (heat-stable toxin), and the strain with serotype O86 carried eaeA (Simujide et al., 2012). 
Capping

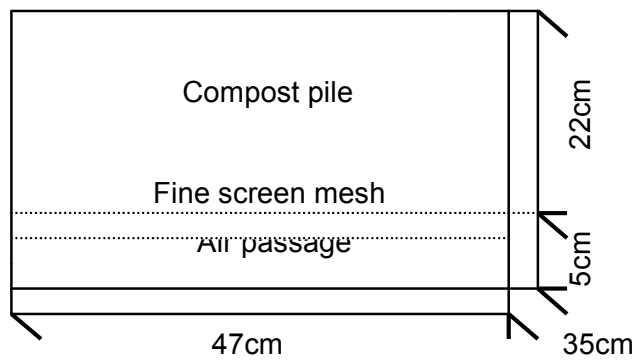

Figure 1. Schematic of composting reactor

\section{Statistical analysis}

Analysis of variances was performed by using ANOVA procedure from SAS software (version 9.0) on data obtained in the composing samples.

Table 1. Characteristics of composting materials

\begin{tabular}{llll}
\hline & Fresh manure & Sawdust & $\mathrm{CaCN}_{2}$ \\
\hline Moisture content $(\%)^{*}$ & $75.48 \pm 0.79^{* *}$ & $7.01 \pm 0.23$ & - \\
\hline Carbon $(\%)^{*}$ & $38.12 \pm 1.71$ & $51.33 \pm 2.12$ & $1.62 \pm 1.24$ \\
\hline Nitrogen $(\%)^{*}$ & $1.60 \pm 0.03$ & $0.13 \pm 0.05$ & $21.27 \pm 0.02$ \\
\hline C/N ratio & 23.83 & 394.85 & 0.08 \\
\hline
\end{tabular}

* On a wet weight basis ** Standard deviation

\section{RESULTS AND DISCUSSION}

The characteristics of the compositing materials were shown in Table 1.

\section{Changes in physico-chemical parameters}

\section{Temperature}

The peak temperatures of $39.0^{\circ} \mathrm{C}-41.1^{\circ} \mathrm{C}$ were achieved in control treatment at $16 \mathrm{~d}-18 \mathrm{~d}$. Fuentes et al. (2009) reported a similar result that during aerobic degradation of dairy cattle dung in laboratory-scale reactors for $105 \mathrm{~d}$, the composting temperature increased to approximately $40{ }^{\circ} \mathrm{C}$ within the first 20 days. However, in test treatments, the time to reach the high temperatures was delayed, that treatment I reached the highest temperatures of $40.1^{\circ} \mathrm{C}-45.9^{\circ} \mathrm{C}$ at $29 \mathrm{~d}-31 \mathrm{~d}$, but such high temperatures did not appear in treatment II during the whole process (Figure 2). The main reason for the result is that the porosities of the composting were influenced by adding $\mathrm{CaCN}_{2}$ into them, which was confirmed from the significant lumping phenomena at the beginning of the composting. The temperatures of each treatment in decreasing total average order were control treatment, treatment I, and treatment II, the differences were statistically significant $(p<0.05)$.

\section{Moisture content}

Our previous study showed that $\mathrm{CaCN}_{2}$ could not thoroughly inactivate the pathogenic $E$. coli in the composting of cow manure in $45 \%$ moisture content condition (data not shown). Therefore, to guarantee both a smooth process for composting and better development for inhibitory effect of $\mathrm{CaCN}_{2}$ on pathogenic $E$. coli, the moisture contents of the composting in the current study were adjusted to $65 \%-70 \%$. The moisture contents of all composting presented the same changes that followed a declining trend. The moisture content of treatment I decreased from an initial value of $66.8 \%$ to $37.6 \%-45.0 \%$, while it decreased from $65.4 \%$ to $55.0 \%-58.6 \%$ and from $68.9 \%$ to $44.1 \%-49.8 \%$ in treatment II and control treatment, respectively. The results revealed that the moisture contents of treatment I and control treatment declined significantly greater than treatment II, owing to the former two lost more moistures because of the higher levels of composting 
temperatures obtained during composting. The moisture contents of each treatment in decreasing total average order were treatment II, control treatment, and treatment I, the differences were statistically significant $(p<0.05)$.
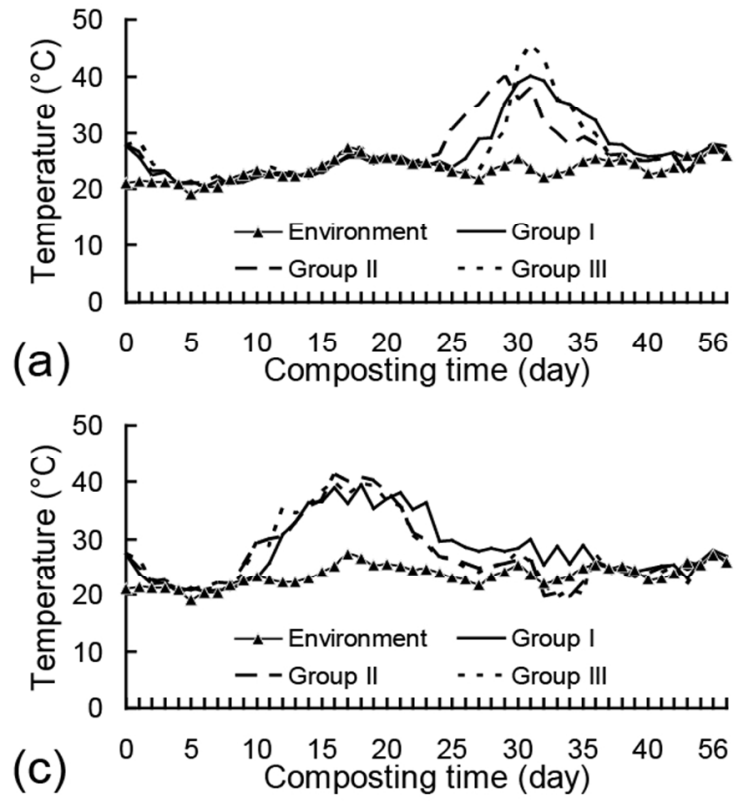

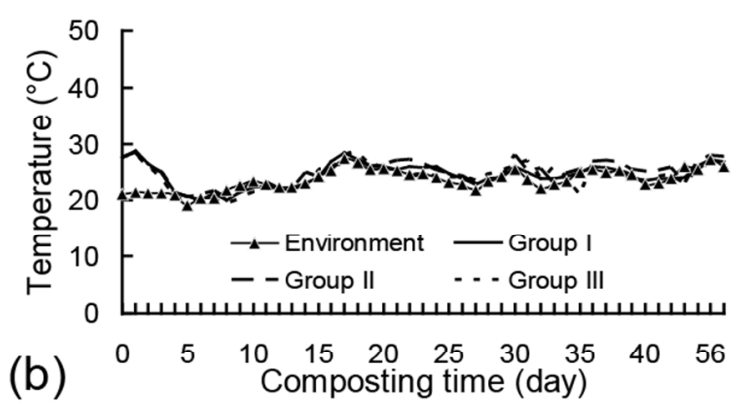

(b)

Figure 2. The temperature $\left({ }^{\circ} \mathrm{C}\right)$ profiles of composting

(a) treatment I; (b) treatment II; (c) control group

\section{pH}

The $\mathrm{pH}$ often rises to 8-9 during successful composting and in matured compost, (Zeng et al., 2007). In the present study, the $\mathrm{pH}$ values of the control treatment fixed 8-9 from $21 \mathrm{~d}$. However, the $\mathrm{pH}$ values of treatment I stabilized in such range from $35 \mathrm{~d}$, while which of treatment II were fluctuating around 9 from $21 \mathrm{~d}$ to the end of the composting (Figure 3 ). The results indicated that all composting kept a favorable environment for the composting materials decomposition during composting. The $\mathrm{pH}$ values of each treatment in decreasing total average order were treatment II, treatment $\mathrm{I}$, and control treatment, the differences were statistically significant $(p<0.05)$.
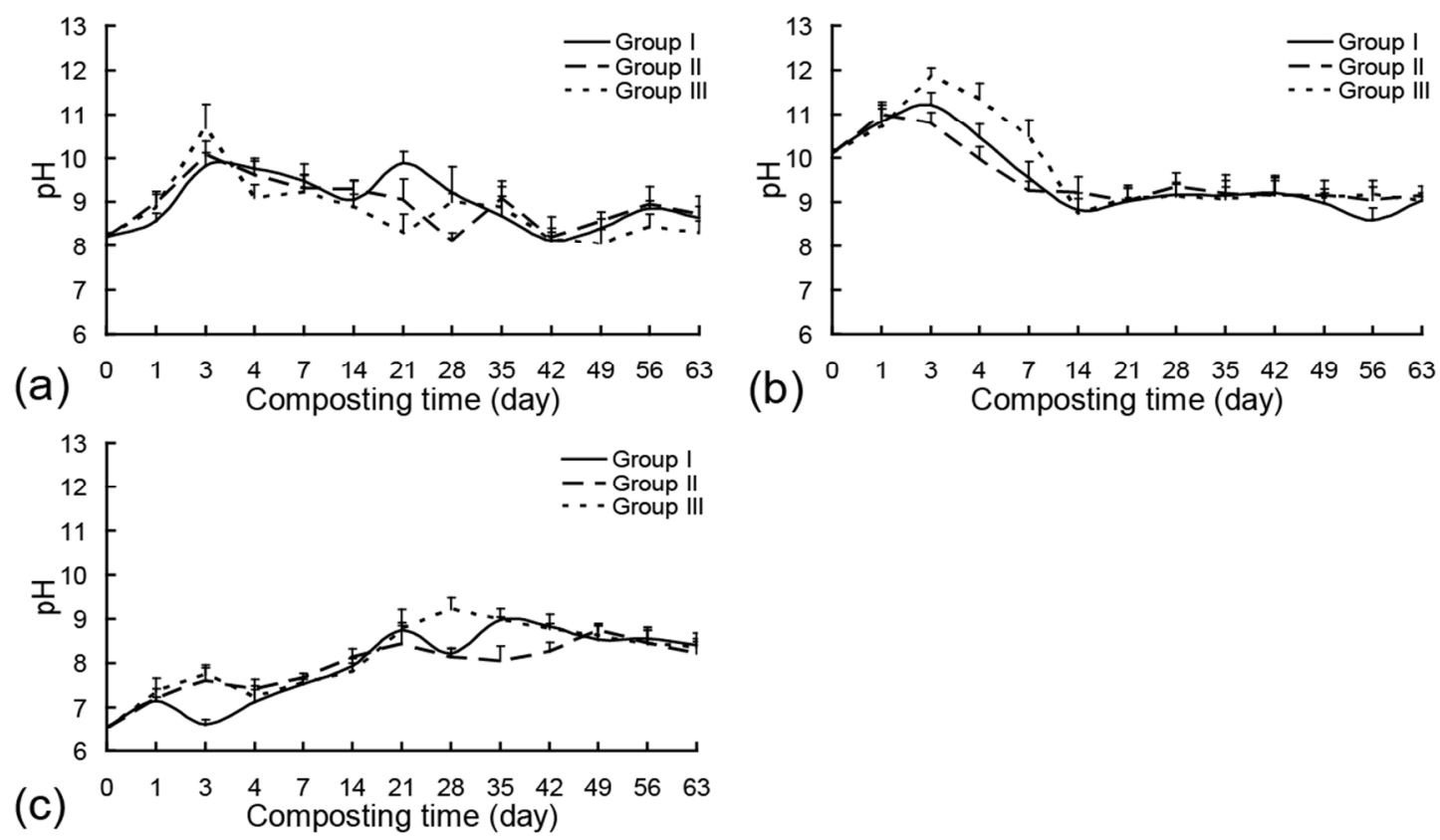

Figure 3. The $\mathrm{pH}$ profiles of composting

(a) treatment I; (b) treatment II; (c) control group 


\section{Total nitrogen ( $T-N)$, total carbon $(T-C)$, and $C / N$ ratio}

The T-N in treatment I and control treatment increased significantly after composting while it decreased slightly in treatment II (Figure 4). The increasing percentage rate was $39.35 \%-41.30 \%$ and $23.70 \%-33.24 \%$ in treatment I and control treatment, respectively, the decreasing percentage rate was $1.26 \%-10.52 \%$ in treatment II. The contents of T-N in each treatment in decreasing total average order were treatment II, treatment I, and control treatment, the differences were statistically significant $(p<0.05)$. The T-C in all composting presented the same changes that followed a gradual declining trend. The contents of T-C in treatment I decreased from an initial value of $43.75 \%$ to $36.80 \%-40.15 \%$, while it decreased from $40.33 \%$ to $36.24 \%-40.12 \%$ and from $45.32 \%$ to $38.00 \%-40.56 \%$ in treatment II and control treatment, respectively. The results revealed that the T-C in treatment I and control treatment expressed a more decrease than treatment II, the changes in the former two were respectively $8.23 \%-15.89 \%$ and $10.50 \%-16.15 \%$ but that in the last was $0.52 \%-10.14 \%$ during composting. The contents of $\mathrm{T}-\mathrm{C}$ in each treatment in decreasing total average order were control treatment, treatment I, and treatment II, the differences were statistically significant $(p<0.05)$.

The initial values of $\mathrm{C} / \mathrm{N}$ ratio in the composting materials ranged from 25 to 30 are most advantageous to organic compounds degradation. However, some other studies showed different results (Li et al., 2001; Michel et al., 2004). In the present study, the initial value of $\mathrm{C} / \mathrm{N}$ ratio in control treatment was 41.16. However, the values decreased to 18.98 and 10.58 in treatment I and treatment II (Figure 5). The $\mathrm{C} / \mathrm{N}$ ratio in treatment I and control treatment showed significant declining trend during composting, but it kept a relative maintenance level in treatment II, which resulted from the lack of carbon in the composting due to the over low initial values of $\mathrm{C} / \mathrm{N}$ ratio and from the majority of nitrogen volatilizing in the form of $\mathrm{NH}_{3}$ that could not be effectively utilized by the microorganisms (Boulter et al., 2000).
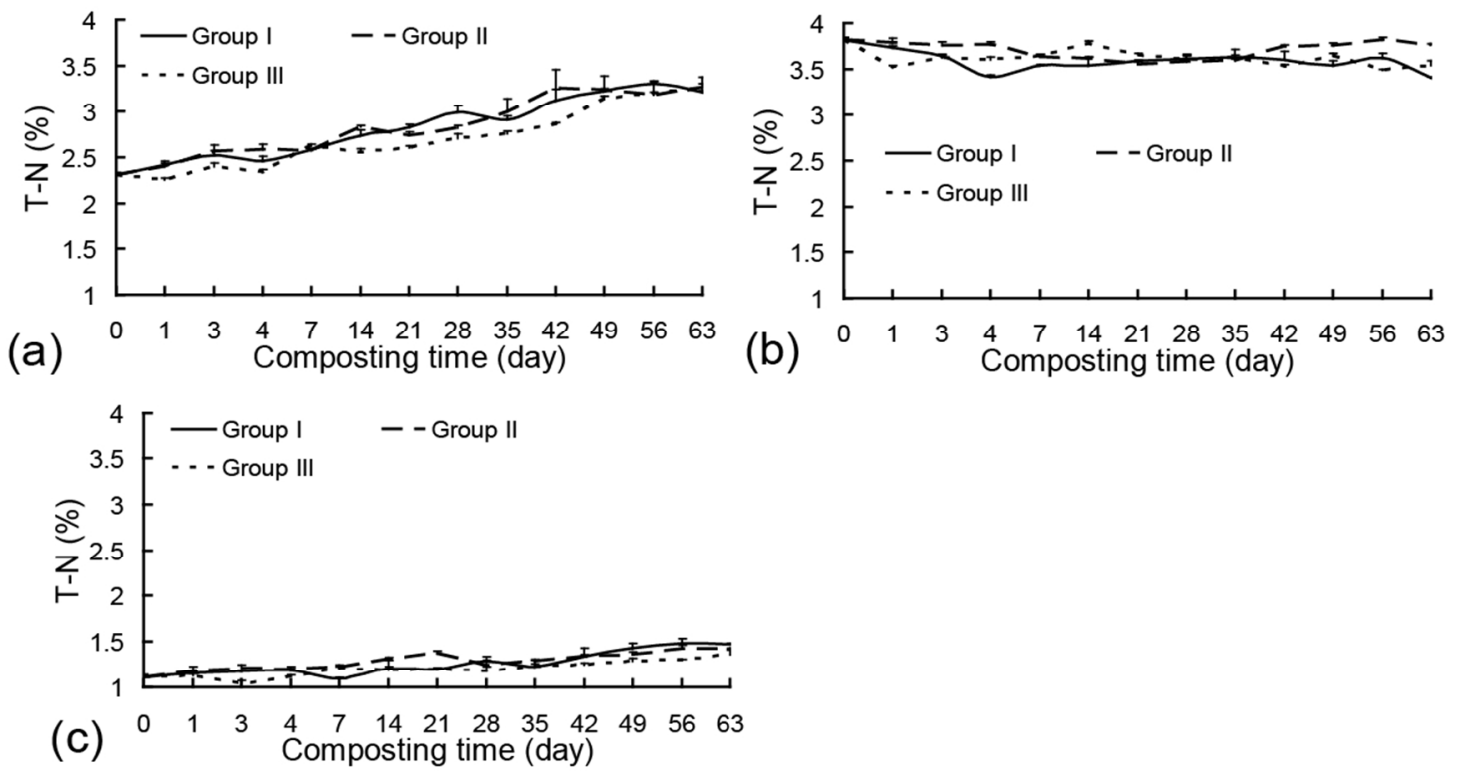

Figure 4. The total nitrogen (T-N) (\%) profiles of composting.

(a) treatment I; (b) treatment II; (c) control group.

\section{Changes in biological parameters \\ Germination index (GI)}

At the first stage of the composting, the values of GI were often low because of the inhibitory effect of excessive $\mathrm{NH}_{4}{ }^{+}$on the seed germination, but $\mathrm{Gl}$ always follows an increasing trend with the proceeding of the composting (Banegas et al., 2007). In the current study, the seeds of rape (Brassica napus L.) did not germinate in all composting until $14 \mathrm{~d}$. At the end of the composting, GI values in control treatment increased to $96.34 \%-112.09 \%$, while in treatment I and treatment II to $140.16 \%-155.70 \%$ and $119.87 \%-129.55 \%$, respectively (Figure 6 ). The results indicated that the seed germination was improved by the addition of $\mathrm{CaCN}_{2}$ into the cow manure composting, which further explained the enhancement of the composting products quality. GI values in each treatment 
in decreasing total average order were treatment I, treatment II, and control treatment, the differences were statistically significant $(p<0.05)$.
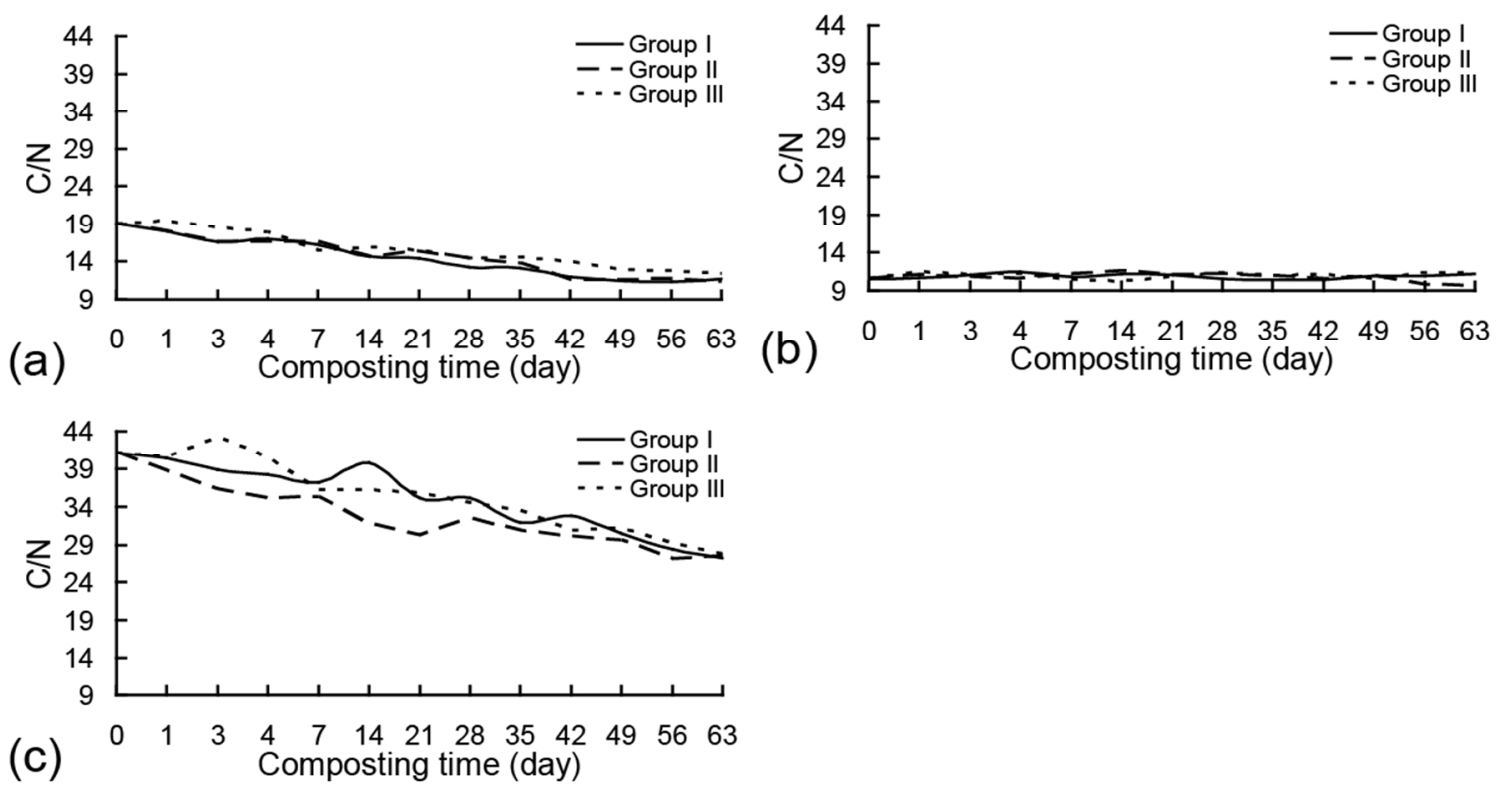

Figure 5. The $\mathrm{C} / \mathrm{N}$ ratio profiles of composting

(a) treatment I; (b) treatment II; (c) control group
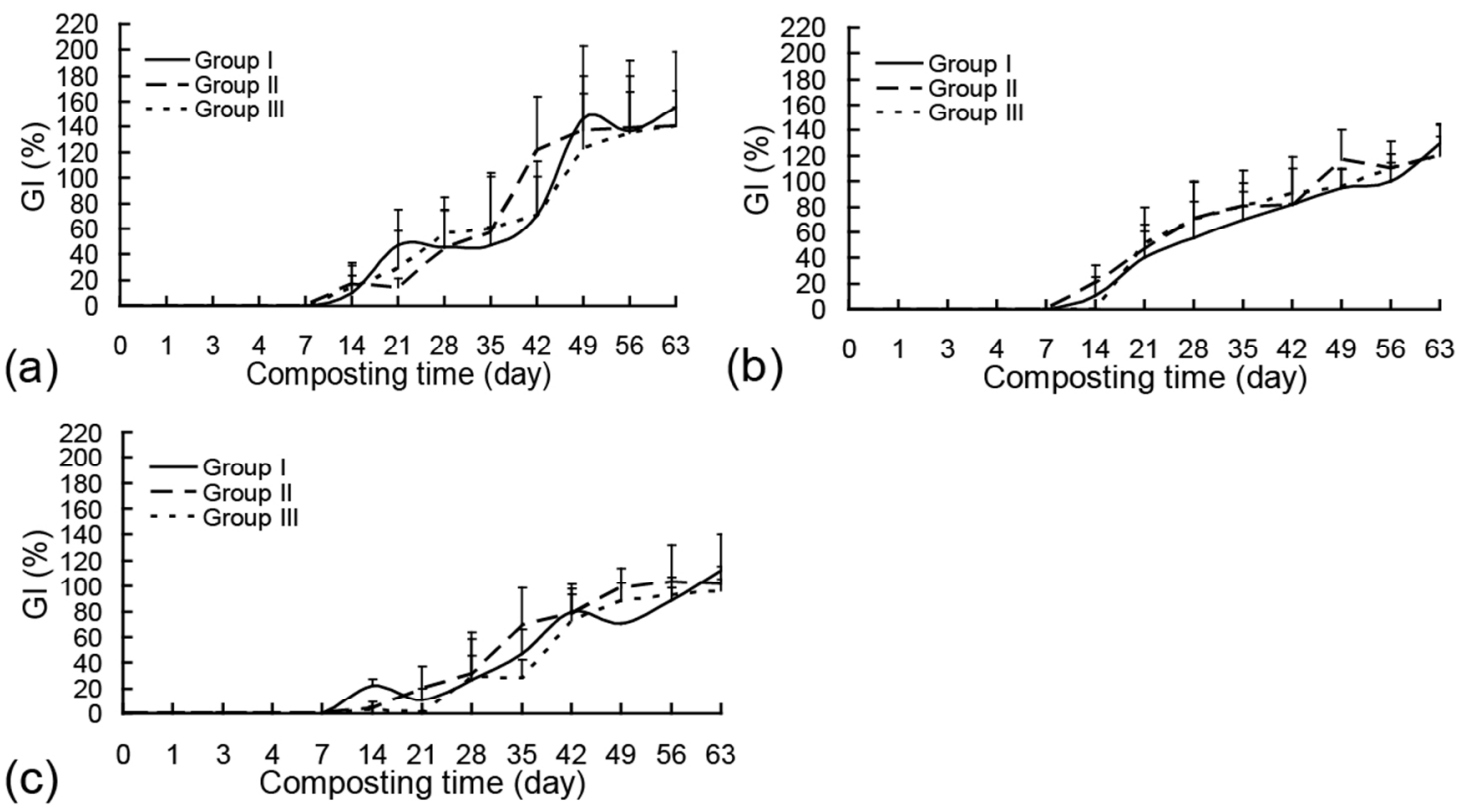

Figure 6. The germination index (GI) (\%) profiles of composting

(a) treatment I; (b) treatment II; (c) control group

\section{Inactivation of E. coli}

Our previous studies showed that $\mathrm{CaCN}_{2}$ could entirely kill the $E$. coli in the cow manure composting (data not shown). Based on the results, we further investigated its effect on pathogenic E. coli with different serotypes in the present study. Because the pathogenic $E$. coli strains which were injected into the composting materials originated from the dairy cow intestines, the modeling test was well targeted and is of immense practical importance. E. coli was not thoroughly detected from $21 \mathrm{~d}$ and $14 \mathrm{~d}$ in treatment I and treatment II when from $35 \mathrm{~d}$ in control treatment (Figure 7). The results demonstrated that the time to inactivate $E$. coli during composting was significantly shortened in the composting added $\mathrm{CaCN}_{2}$ compared with control treatment, indicating that the composting could 
reach the sanitary standard earlier by adding $\mathrm{CaCN}_{2}$. In addition, with the increase of additive quantities of $\mathrm{CaCN}_{2}$, the effectiveness for inactivation of $E$. coli was also improved obviously. Other test indicated that the pathogen Fusarium oxysporum f. sp. cucumberinum population in soil treated with $\mathrm{CaCN}_{2}$ was negatively related to the concentration of $\mathrm{CaCN}_{2}$ (Shi et al., 2009). Otherwise, our results showed that the inactivation efficacy of $\mathrm{CaCN}_{2}$ on $E$. coli differed with respect to serotypes, that $E$. coli $\mathrm{O} 2$ was not respectively detected from $21 \mathrm{~d}, 7 \mathrm{~d}$ and $35 \mathrm{~d}$ in treatment I, treatment II and control treatment, while $E$. coli $O 78$ from $21 \mathrm{~d}, 14 \mathrm{~d}$ and $35 \mathrm{~d}$, and $E$. coli 086 from $14 \mathrm{~d}, 7 \mathrm{~d}$ and $28 \mathrm{~d}$. The phenomenon was resulting mostly from the differences in the survival of $E$. coli strains with different serotypes in the manure (Fukushima et al., 1999; Jiang et al., 2003).
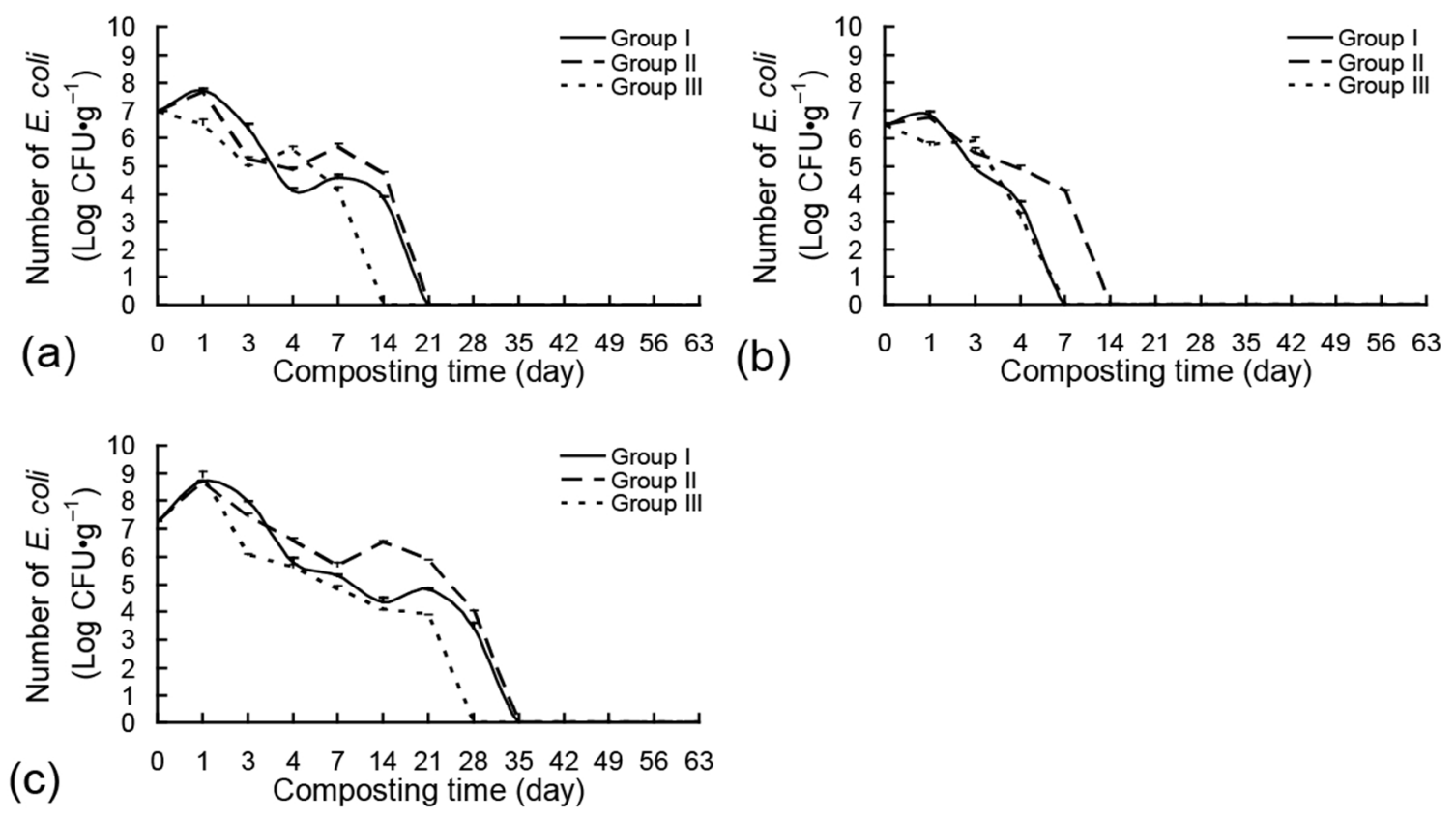

Figure 7. The number of $E$. coli $\left(\log \mathrm{CFU} \cdot \mathrm{g}^{-1}\right)$ profiles of composting (a) treatment I; (b) treatment II; (c) control group

\section{CONCLUSIONS}

1. The time to reach the high temperatures was delayed with the addition of $2 \%$ and $3 \% \mathrm{CaCN}_{2}$ into the compostable substrate.

2. The environment suitable for composting process was not influenced by the addition of $\mathrm{CaCN}_{2}$.

3. The $\mathrm{C} / \mathrm{N}$ ratio in the composting added $2 \% \mathrm{CaCN}_{2}$ showed an obvious declining trend, while kept a relative maintenance level in the composting added $3 \% \mathrm{CaCN}_{2}$.

4. With the addition of $2 \%$ and $3 \% \mathrm{CaCN}_{2}$, the phytotoxicity of the composting was decreased significantly.

5. The time to entirely inactivate pathogenic E. coli in the composting could be shortened through adding $2 \%$ and $3 \% \mathrm{CaCN}_{2}$ into the compostable substrate, and with the increase of the addition doses, the inhibitory effect of $\mathrm{CaCN}_{2}$ on $E$. coli was significantly improved.

\section{ACKNOWLEDGEMENTS}

This work was supported by the Major Special Project of National Dairy Industry of China (2006BAD04A15), the Key Project of Natural Science Fund of Inner Mongolia, China (200607010403), the Talent Fund of Inner Mongolia, China, and the National Natural Science Funds, China (31060318). 


\section{REFERENCES}

Banegas V., Moreno J.L., Moreno J.I., García C., León G. and Hernández T. (2007), Composting anaerobic and aerobic sewage sludges using two proportions of sawdust, Waste Management, 27, 1317-1327.

Bao S.D. (2000), Soil and agricultural chemistry analysis, Third Edition, China Agriculture Publishiling House, Beijing (in Chinese).

Bletsos F.A. (2005), Use of grafting and calcium cyanamide as alternatives to methyl bromide soil fumigation and their effects on growth, yield, quality and Fusarium wilt control in melon, Journal of Phytopathology, 153, 155-161.

Bletsos F.A. (2006), Grafting and calcium cyanamide as alternatives to methyl bromide for greenhouse eggplant production, Scientia Horticulturae, 107, 325-331.

Boulter J.I., Boland G.J. and Trevors J.T. (2000), Compost: A study of the development process and end-product potential for suppression of turfgrass disease, World Journal of Microbiology and Biotechnology, 16, 115-134.

Bourbos V.A., Skoudridakis M.T., Darakis G.A. and Koulizakis M. (1997), Calcium cyanamide and soil solarization for the control of Fusarium solani f.sp. cucurbitae in greenhouse cucumber, Crop Protection, 16, 383-386.

Cohen M.B., Nataro J.P., Bernstein D.I., Hawkins J., Roberts N. and Staat M.A. (2005), Prevalence of diarrheagenic Escherichia coli in acute childhood enteritis: a prospective controlled study, Journal of pediatrics, 146, 54-61.

Fuentes B., Jorquera M. and Mora Mde L. (2009), Dynamics of phosphorus and phytate-utilizing bacteria during aerobic degradation of dairy cattle dung, Chemosphere, 74, 325-331.

Fukushima H., Hoshina K. and Gomyoda M. (1999), Long-term survival of shiga toxin-producing Escherichia coli O26, O111, and 0157 in bovine feces, Applied and Environmental Microbiology, 65, 5177-5181.

Huang G.F., Wong J.W.C., Wu Q.T. and Nagar B.B. (2004), Effect of C/N on composting of pig manure with sawdust, Waste Management, 24, 805-813.

Jiang X., Morgan J. and Doyle M.P. (2003), Fate of Escherichia coli O157:H7 during composting of bovine manure in a laboratory-scale bioreactor, Journal of Food Protection, 66, 25-30.

Li G., Zhang F., Sun Y., Wong J.W.C. and Fang M. (2001), Chemical evaluation of sewage sludge composting as a mature indicator for composting process, Water, Air \& Soil Pollution, 132, 333-345.

Michel F.C., Pecchia J.A., Rigot J. and Keener H.M. (2004), Mass and nutrient losses during the composting of dairy manure amended with sawdust or straw, Compost Science \& Utilization, 2, 323-334.

Shi K., Wang L., Zhou Y.H., Yu Y.L. and Yu J.Q. (2009), Effects of calcium cyanamide on soil microbial communities and Fusarium oxysporum f. sp. Cucumberinum, Chemosphere, 75, 872-877.

Simujide H., Aorigele C., Wang C.J., Li Y. and Bai T. (2012), Occurrence and characteristics of virulence genes of Escherichia coli strains isolated from healthy dairy cows in Inner Mongolia, China, Brazilian Journal of Microbiology, 43(2), 528-534.

Sundberg C., Smårs S. and Jönsson H. (2004), Low pH as an inhibiting factor in the transition from mesophilic to thermophilic phase in composting, Bioresource Technology, 9, 145-150.

Wichuk K.M. and McCartney D. (2007), A review of the effectiveness of current time-temperature regulations on pathogen inactivation during composting, Journal of Environmental Engineering and Science, 6, 573-586.

Zeng G.M., Huang D.L., Huang G.H., Hu T.J., Jiang X.Y., Feng C.L., Chen Y.N., Tang L. and Liu H.L. (2007), Composting of lead-contaminated solid waste with inocula of white-rot fungus, Bioresource Technology, 98, 320-326. 